\title{
Synthesis and Cations Binding Properties of a New C,N-bipyrazolic Ligand
}

\author{
Ahmed Attayibat. Smaail Radi. ${ }^{\star}$ Abdelkrim Ramdani. Yahya Lekchiri, ${ }^{\dagger}$ Brahim Hacht, ${ }^{\ddagger}$ \\ Maryse Bacquet.' Stêphanie Willai, ${ }^{\S}$ and Michel Morcellet ${ }^{\S}$

\begin{abstract}
Laboratoire de Chimie Organique Physique, Departement de Chimie, Oujda, Maroc. "E-mail: radi_smaallayahoo,fr "Laboratoire de biochimie, Departement de Biologie, Oujda, Maroc

"Laboratoire de Spéciation et de Surveillance de la Pollution en Méditerranee, Departement de Chimie, Oujda, Maroc ${ }^{\$}$ Laboratoire de Chimie Macromoleculaire, Universite des Sciences et Technologies de Lille, 59655 Villenetve d'Ascq, France
\end{abstract} \\ Received July 25, 2006

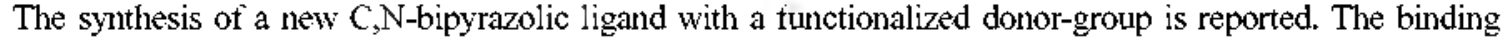
properties of the ligand and two other ligand of similar structures towards heavy metal ions $\left(\mathrm{Hg}^{21}, \mathrm{Cd}^{21}, \mathrm{~Pb}^{21}\right.$, $\left.\mathrm{Zn}^{21}, \mathrm{Cu}^{2}\right)$ and alkaline metal ions $\left(\mathrm{K}^{\prime}, \mathrm{Na}^{\prime}, \mathrm{Li}^{\prime}\right)$ were studied by a liquid-liquid extraction process and the extracted cation percentage was determined by atomic absorption measurements. The selectivity of the ligand to $\mathrm{Hg}(\mathrm{II})$ has been mentioned in the abstract.
\end{abstract}

Key Words : Synthesis, Bipyrazole ligands, Complexing properties, Liquid-liquid extraction, $\Lambda$ tomic absorption

\section{Introduction}

There is a continuing interest in the preparation of functionalized pyrazole derivatives. This is evident from the large number of articles, several of them being reviews. ${ }^{1,2}$ Moreover, polydentate pyrazolic receptors are well known for their ability to complex not only alkali cations ${ }^{3-7}$ but also to form stable complexes with transition metal ions. ${ }^{8-11}$ These complexes are so stable that it is often difficult to obtain the free macrocycles from them.

In our recent work, ${ }^{12-18}$ a series of acyclic pyrazole compounds containing one to four pyrazole rings were prepared and demonstrated to extract only transition metal cations whereas macrocyclic pyrazolic compounds are expected to form stable complexes both with transition and alkali metals. However, complexation studies of a kind of bibyrazole ligands are less met in the literature.

In this paper we describe the synthesis of new C,Nbipyrazolic structure $\mathbf{4}$ (Fig. 1) with a donor heteroatom in a side arm and its binding ability towards alkali and transition

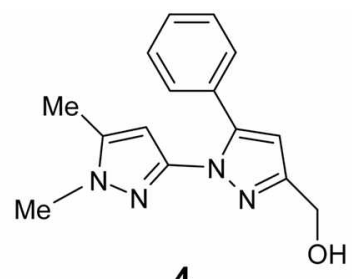<smiles>Cc1cc(-n2nc(CO)cc2C)n(C)n1</smiles>

5

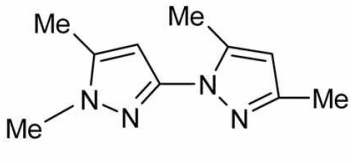

6 metal ions compared to two other similar structures 5 and 6 (Fig. 1) which are equally studied here for there complexation properties for the first time. It has been found that a donor atom in a side chain of lariat ethers increases the binding ability of the macrocycle. ${ }^{19-21}$ The presence of a functional chain also provides this structure with the possibility of being immobilized on the surface of a solid material (organic resin or silica gel) by covalent bonding.

\section{Results and Discussion}

The route to prepare the new bipyrazole compound 4 is shown in Scheme 1. Compound 2 was prepared from commercially available 3(5)-amino-5(3)-methylpyrazole 1 by diazotation in $\mathrm{HCl}$ followed by reduction with Tin chloride ${ }^{22}$ and the intermidiate diamine is not isolated but has immediately undergone a condensation with the $\beta$ diketones $^{4}$ to give the ester 2 as a white solid in a $36 \%$ yield. The methylation of this product in the presence of $t$-BuOK as base led to one isolated $\alpha$-isomer ${ }^{23}$ product 3 in a $29 \%$
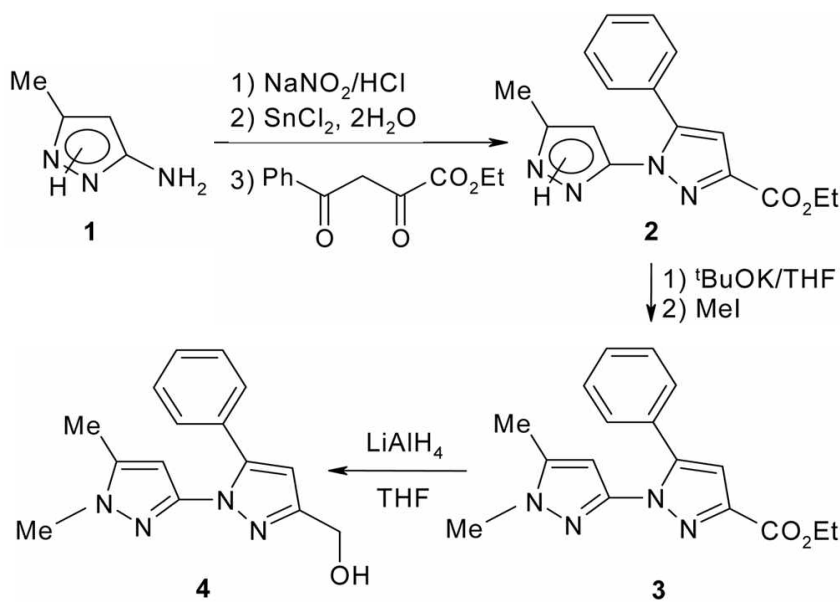

Scheme 1 
Table 1. Yiclds of extraction of individual heavy and alkali metal ions

\begin{tabular}{ccccccccc}
\hline & Mercury & Cadmium & Lead & Copper & Zinc & Potassium & Sodium & Lithium \\
\hline $\mathbf{4}$ & 27 & 9 & 11 & 19 & 4 & 0 & 0 & 0 \\
$\mathbf{5}$ & 46 & 6 & 7 & 18 & 3 & 0 & 0 & 0 \\
6 & 10 & 7 & 12 & 20 & 0 & 0 & 0 & 0 \\
\hline
\end{tabular}

Table 2. Yiclds of competitive extraction of various heavy and alkali metal ions

\begin{tabular}{cccccccc}
\hline & Mercury & Cadmium & Lead & Zinc & Potassium & Sodium & Lithium \\
\hline $\mathbf{4}$ & 45.11 & 6.20 & 6.22 & 3.77 & 0 & 0 & 0 \\
$\mathbf{5}$ & 47.77 & 6.65 & 1.30 & 0.46 & 0 & 0 & 0 \\
\hline
\end{tabular}

yield. Finally, the compound 3 was convert to the target product 4 using $\mathrm{LiAlH}_{4}$ as agent of reduction.

Structures of all compounds were determined on the basis of the corresponding analytical and spectroscopic data.

Liquid-liquid extraction of individual cations. We used this method in order to study the complexation properties of this new bipyrazolic ligand 4 compared to two other similar bipyrazole compounds $5^{2+}$ and $6^{4}$ which are equally studied here for their complexation properties for the first time. The study of individual extraction of cations was carried out toward $\mathrm{Hg}^{2+}, \mathrm{Cd}^{2+}, \mathrm{Pb}^{2+}, \mathrm{Zn}^{2+}, \mathrm{Cu}^{2+}, \mathrm{K}^{+}, \mathrm{Na}^{+}$and $\mathrm{Li}^{+}$cations. Metal nitrates were extracted into the organic phase by complex formation with ligands. The percentage limits of extraction determined by atomic absorption measurements are given in Table 1 .

Results in Table 1 show that in analogy to our previous work $^{12-18}$ in which acyclic pyrazoles extract only the transition metal cations when the macrocyclic pyrazolic compounds are expected to form stable complexes both with transition and alkali metals, we demonstrate also here an affinity of these acyclic structures 4-6 only with the transition metal cations, with no complexation being observed toward alkali cations.

The affinity of these hosts is especially high for mercury (II) ion. This is not surprising if the high donor properties of nitrogen towards this metal are considered.

Bipyrazole groups act as convergent chelating bidentate donors. The term convergent refers to the nitrogen donor atoms coordinating to the same metal centre leading thus to a five membered ring which is part of several such rings when the whole ligand is considered. It is well known ${ }^{25}$ that five membered ring chelates are more stable than sixmembered and four-membered ones.

In analogy to the literature in which a donor atom in a side chain of a lariat ethers increases the binding ability of the macrocycle, ${ }^{19-21}$ the comparison between 5 with a donor atom in a side chain and 6 without a donor atom shows that there is practically a change in the percentage of complexation especially in case of $\mathrm{Hg}^{2+}$.

It seemed that $\mathrm{Hg}(\Pi)-4$ should be stayed more in the organic layer than the aqueous layer probably due to solubility. However, We notice a decrease of complexation towards $\mathrm{Hg}^{2+}$ for the compound $\mathbf{4}$ compared to 5 .

The affinity to other metal ions are practically weak and
Table 3. Selectivity ratios in competitive conditions

\begin{tabular}{cccc}
\hline & Mercury/Lead & Mercury/Cadmium & Mercury/Zinc \\
\hline $\mathbf{4}$ & 7.25 & 7.27 & 11.96 \\
$\mathbf{5}$ & 35.20 & 7.18 & 103.84 \\
\hline
\end{tabular}

identical. We can thus suggest an important selectivity for these ligands 4 and 5 toward mercury.

Competitive liquid-liquid extraction measurements. We have chosen ligands $\mathbf{4}$ and $\mathbf{5}$ which seem to have good selective properties towards $\mathrm{Hg}^{2+}$. By competitive extraction from aqueous solutions of $\mathrm{Hg}^{2+}, \mathrm{Cd}^{2+}, \mathrm{Pb}^{2+}, \mathrm{Zn}^{2+}, \mathrm{K}^{+}, \mathrm{Na}^{+}$ and $\mathrm{Li}^{+}$nitrates with a $\mathrm{CH}_{2} \mathrm{Cl}_{2}$ solution of ligand 4 or 5 , we have obtained the results given in Table 2 .

These obtained values are in perfect agreement with those measured by separate cation extraction. Indeed, in this competitive extraction, we notice a high affinity only for mercury with zero extraction of alkali cations and a weak extraction of other transition metals. We can thus conclude that these ligands are selective with the extraction of $\mathrm{Hg}$ (II). Moreover, the $\mathrm{Hg}^{2+} /$ cation selectivity ratio obtained (Table 3 ) in these competitive conditions, shows the good mercury selectivity of 4 and 5 .

\section{Conclusion}

In conclusion, metal cations and macrocyclic pyrazolic compounds are expected to form stable complexes both with transition and alkali metals, while the acyclic bipyrazole ligands reported here only form complexes with transition metal cations. They do not complex alkali metal cations at all. The bipyrazolic ligands with a donor atom in a side chain show a high affinity and a good selectivity for mercury.

\section{Experimental Section}

All solvents and other chemicals, obtained from usual commercial sources, were of analytical grade and used without further purification. The ${ }^{1} \mathrm{H} N M R$ and ${ }^{13} \mathrm{C} N M R$ spectra were obtained with a Bruker $\mathrm{AC} 300$ spectrometer (operating at $300.13 \mathrm{MHz}$ for ${ }^{1} \mathrm{H} \mathrm{NMR}$ and $75 \mathrm{MHz}$ for ${ }^{13} \mathrm{C}$ NMR). Elemental analysis were performed by Microanalysis Central Service (CNRS). Molecular weights were determined on a JEOL JMS DX-300 Mass Spectrometer. 
Atomic absorption measurements were performed by Spectra Varian A.A. 400 Spectrophotometer. The IR spectra were taken with potassium bromide discs on Perkin Elmer 1310 spectrometer.

Synthesis of 3-ethylcarboxylate-1-(4-methylpyrazol)yl5-phenyl pyrazole 2 . To a cooled $\left(-5^{\circ} \mathrm{C}\right)$ solution of $\mathrm{HCl} 6$ $\mathrm{N}(75 \mathrm{~mL})$ and aminopyrazole $(0.123$ mole, $12 \mathrm{~g})$ was successively added $\mathrm{NaNO}_{2} 1 \mathrm{M}(125 \mathrm{~mL})$ and a very cooled solution of $\mathrm{HCl} 6 \mathrm{~N}(50 \mathrm{~mL})$ containing $\mathrm{SnCl}_{2}, 2 \mathrm{H}_{2} \mathrm{O}(0.25$ mole, $56.5 \mathrm{~g}$ ). The mixture was let under agitation at $0^{\circ} \mathrm{C}$ for $4 \mathrm{~h}$ and then evaporated to dryness. The obtained residue was taken by absolute ethanol $(150 \mathrm{~mL})$, filtered and the filtrate was evaporated. The residue was treated with ethyl acetyl pyruvate $\left(9.49 \times 10^{-2}\right.$ mole, $\left.15 \mathrm{~g}\right)$ in absolute ethanol $(200 \mathrm{~mL})$. The mixture was thereafter refluxed for $2 \mathrm{~h}$ and then placed in the fridge for $3 \mathrm{~h}$. The formed precipitate was dissolved in water, neutralized with sodium carbonate and extracted with $\mathrm{CH}_{2} \mathrm{Cl}_{2}(3 \times 20 \mathrm{~mL})$. The organic solution was dried with $\mathrm{Na}_{2} \mathrm{SO}_{4}$ and evaporated to dryness. The residue was recrystallized in diethyl ether to give $(13.1 \mathrm{~g}, 36 \%)$ of compound 2 as a white solid. $\mathrm{R} f=0.52\left(\mathrm{CH}_{2} \mathrm{Cl}_{2} / \mathrm{ethyl}\right.$ acetate, $6 / 4) ; \mathrm{mp}=149-151{ }^{\circ} \mathrm{C}$ (from diethyl ether); ${ }^{1} \mathrm{H}$ NMR (300 $\left.\mathrm{MHz} ; \mathrm{CDCl}_{3} ; \mathrm{Me}+\mathrm{Si}\right) \delta_{\mathrm{t}}: 1.39(3 \mathrm{H}, \mathrm{t}, \mathrm{Et}, J=7.2 \mathrm{~Hz}), 2.23(3 \mathrm{H}$, s, Me), 4.41 (2H, q, Et, $J=7.2 \mathrm{~Hz}) ; 6.00(1 \mathrm{H}, \mathrm{s}, \mathrm{H}-5-\mathrm{Pyr})$, $6.98(1 \mathrm{H}, \mathrm{s}, \mathrm{H}-\mathrm{pyr}), 7.32\left(5 \mathrm{H}\right.$, br s, ph); ${ }^{13} \mathrm{C} \mathrm{NMR}\left(\mathrm{CDCl}_{3}\right) \delta$ : $11.16 ; 14.37 ; 61.12 ; 100.61 ; 109.38 ; 128.39 ; 128.62 ; 128.80$; $140.72 ; 144.57 ; 145.60 ; 162.36$. Anal. Calc. for $\mathrm{C}_{16} \mathrm{H}_{1} \mathrm{~N}_{4} \mathrm{O}_{2}$, $1 \mathrm{H}_{2} \mathrm{O}: \mathrm{C} 61.08 ; \mathrm{H} 5.73 ; \mathrm{N} 17.82 \%$; Found: C 61.02; H 5.79; N 17.78. IR: $v_{\max } / \mathrm{cm}^{-1} 1700(\mathrm{C}=\mathrm{O}) ; m / z: 297\left(\mathrm{MH}^{+}\right)$.

Synthesis of 3. A mixture of compound $2(3 \mathrm{~g}, 10.13$ mmol) and potassium tert-butoxide $(1.14 \mathrm{~g}, 10.17 \mathrm{mmol})$ in anhydrous THF $(80 \mathrm{~mL})$ was stirred under reflux for $30 \mathrm{mn}$ and cooled to $0^{\circ} \mathrm{C}$. Then, a solution of methyl iodide $(7.2 \mathrm{~g}$, $50.7 \mathrm{mmol})$ in anhydrous THF $(10 \mathrm{~mL})$ was slowly added and the mixture was refluxed for $4 \mathrm{~h}$, filtered and evaporated to dryness. The residue obtained was purified on silica (ethyl acetate / hexane : $4 / 6)$ to give $(0.93 \mathrm{~g}, 29 \%)$ of 3 as a white solid; mp 91-92 ${ }^{\circ} \mathrm{C}$ (from $\mathrm{CH}_{2} \mathrm{Cl}_{2}$ ); $\mathrm{Rf}=0.85$ (ethyl acetate / $\left.\mathrm{CH}_{2} \mathrm{Cl}_{2}: 4 / 6\right)$; 'H NMR (300 MHz; $\left.\mathrm{CDCl}_{3} ; \mathrm{Me}_{4} \mathrm{Si}\right) \delta_{\mathrm{H}}: 1.39$ $(3 \mathrm{H}, \mathrm{t}, \mathrm{Et}, J=7.2 \mathrm{~Hz}), 2.22$ ( $3 \mathrm{H}, \mathrm{s}, \mathrm{Me}), 3.73$ (3H, s, N-Me), $4.41(2 \mathrm{H}, \mathrm{q}, \mathrm{Et}, J=7.2 \mathrm{~Hz}), 5.87(1 \mathrm{H}, \mathrm{s}, \mathrm{H}-5-\mathrm{Pyr}), 6.98(1 \mathrm{H}$, s, H-5-Pyr), $7.32\left(5 \mathrm{H}\right.$, br s, ph); ${ }^{13} \mathrm{C} \mathrm{NMR}\left(\mathrm{CDCl}_{3}\right) \delta: 11.30$; $14.40 ; 36.34 ; 60.98 ; 101.47 ; 109.23 ; 128.29 ; 128.71 ; 129.40$; $139.74 ; 144.47 ; 145.39 ; 146.07 ; 162.4417 .82$; Anal. Calc. For $\mathrm{C}_{17} \mathrm{H}_{18 \mathrm{~N}_{4} \mathrm{O}_{2}}$ : C 65.80; H 5.80; N 18.06\%; Found: C 66.13; H 5.94; N 17.82; IR: $v_{\text {nax }} / \mathrm{cm}^{-1} 1700(\mathrm{C}=\mathrm{O}) ; m / z: 311\left(\mathrm{MH}^{+}\right)$.

Synthesis of 4. To a solution of $\mathrm{LiAlH}_{4}(400 \mathrm{mg}, 10.52$ mmol) in anhydrous THF $(20 \mathrm{~mL})$ cooled at $0^{\circ} \mathrm{C}$, was slowly added bipyrazole $3(1.5 \mathrm{~g} ; 4.84 \mathrm{mmol})$ in $30 \mathrm{~mL}$ of THF. The mixture was stirred under reflux for $2 \mathrm{~h}$ and cooled to $0^{\circ} \mathrm{C}$. To a resulting mixture was successively added water $(0.4 \mathrm{~mL}), 15 \%$ aqueous sodium hydroxide $(0.4$ $\mathrm{mL})$ and water $(1.2 \mathrm{~mL})$. The solid material was filtered and the residue was washed with hot THF. The filtrate and THF washings were concentrated under reduced pressure and purified on silica to give $(1.12 \mathrm{~g}, 86 \%)$ of 4 as a white solid. mp 111-113 ${ }^{\circ} \mathrm{C}$ (from $\mathrm{THF}$ ); $\mathrm{Rf}=0.22$ (ethyl acetate $/$
$\left.\mathrm{CH}_{2} \mathrm{Cl}_{2}: 4 / 6\right)$; 'H NMR (300 MHz; $\left.\mathrm{CDCl}_{3} ; \mathrm{Me}+\mathrm{Si}\right) \delta_{\mathrm{II}}: 2.19$ $(3 \mathrm{H}, \mathrm{s}, \mathrm{Me}), 3.75(3 \mathrm{H}, \mathrm{s}, \mathrm{N}-\mathrm{Me}), 4.76\left(2 \mathrm{H}, \mathrm{s}, \mathrm{CH}_{2}\right), 5.64$ (1H, s, H-5-pyr), 6.45 (1H, s, H-5-pyr), 7.32 (5H, br s, ph); ${ }^{13} \mathrm{C} \mathrm{NMR}\left(\mathrm{CDCl}_{3}\right) \delta: 11.28 ; 36.25 ; 59.10 ; 100.58 ; 105.63$; $128.22 ; 128.37 ; 128.72 ; 130.19 ; 139.59 ; 144.86 ; 146.55$; 153.17. Anal. Calc. For $\mathrm{C}_{15} \mathrm{H}_{1} \mathrm{~N}_{4} \mathrm{O}: \mathrm{C} 67.16 ; \mathrm{H} 5.97 ; \mathrm{N}$ 20.89\%. Found: C 67.57; H 6.20; N 20.46; IR: $v_{\max } / \mathrm{cm}^{-1}$ $3410(\mathrm{HO}) ; \mathrm{m} / z: 269\left(\mathrm{MH}^{+}\right)$.

Extraction experiments: A solution of $7 \times 10^{-5} \mathrm{M}$ of the ligand in $\mathrm{CH}_{2} \mathrm{Cl}_{2}(50 \mathrm{~mL})$ was stirred for $2 \mathrm{~h}$ with an aqueous solution $(50 \mathrm{~mL})$ of metal nitrates $\left(7 \times 10^{-5} \mathrm{M}\right)$; the complexation was followed by measuring the concentration of cations in an aqueous solution by atomic absorption. The temperature remained constant during all the experiments at $25^{\circ} \mathrm{C}$ and at $\mathrm{pH} 7$ measured by a $\mathrm{pH}$-meter. This was explained by the absence of nitrogen protons in ligands.

\section{References and Notes}

I. Trofimenko, S. Chem. Rev: 1972, 72,497-509.

2. Trofimenko, S. Prog. Inorg. Chem. 1986, 34, 115-210.

3. Lupo, B.; Tamago, G Bull. Soc. Chim. Fr. 1984, 2, 473-480.

4. Ramdani, A.; Tarrago, G Tetrahedron 1981, 37, 987-990.

5. Gal, M.; Tarrago, G; Steel, P.; Marzin, C. New J. Chem. 1985, 9, $617-620$.

6. Boudouche, S.; Coquelet, C.; Jacquet, L.; Marzin, C.; Sandeaux, $\mathrm{R}$; Tarrago, G.J. Incl. Phenom, 1993, 16, 69-80.

7. Malek, F.; Persin, M.; Ramdani, A.; Sarrazin, J.; Zidane, I. New J. Chem, 2002, 26, 876-882.

8. Elguero, J.; Espada, M.; Ramdani, A.; Tarrago, G. J. Heterocyd. Chem, 1980,17, 137-142.

9. Marzin, C.; Tarrago, G; Gal, G.; Zidane, I.; Hours, T.; Lemer, D.; Andrieux, C.; Camp, H.; Saveant, J. M. Inorg. Chem, 1986, 25, $1775-1778$.

10. Bol, J. E.; Mars, B.; Gonesh, G.; Driessen, W. L.; Goubitz, K.; Reedijk, J. Heterocycles 1997, 45, 1477-149l.

11. Mary, F.; Marzin, C.; Salhi, S.; Tarrago, G. Suprontol. Chent. $1993,3,57-61$.

12. Radi, S.; Ramdani, A.; Lekchiri, Y.; Morcellet, M.; Crini, G.; Morcellet, J.; Janus, L. Eur. Pohmi. J. 2000, 36, 1885-1892.

13. Radi, S.; Ramdani, A.; Lekchiri, Y; Morcellet, M.; Crini, G.; Janus, L.; Bacquet, M. New J. Chen. 2003, 27, 1224-1227.

14. Malek, F.; Ramdani, A.; Radi, S. J. Chem. Res. 2004, 9, 640-641.

15. Radi, S.; Ramdani, A.; Lekchiri, Y.; Morcellet, M.; Crini, G.; Morcellet, J.; Janus, L. J. Chen. Res. 2003, 11, 712-714.

16. Radi, S.; Ramdani, A.; Lekchiri, Y.; Morcellet, M.; Crini, G.; Janus, L. Tetrahedron 2004, 60,939-942.

17. Malek, F.; Ramdani, A.; Zidane, I.; Radi, S. Equ: Polym. J. 2005, $41,817-821$.

18. Malek, F.; Ramdani, A.; Zidane, I.; Yahyi, A.; Radi, S. Tetrahedron 2005, 61, 2995-2998.

19. Schultz, R. A.; Dishong, D. M.; Gokel, G W. Tetrahedron Lett. $1981,22,2623-2626$.

20. Davidson, R. B.; Izalt, R. M.; Christensen, J. J.; Schultz, R. A.; Dishong, D. M.; Gokel, G. W. J. Org. Chem. 1984, 49, 5080-5084.

2I. Kaifer, A.; Gustowski, D. A.; Echegoyen, L. A.; Gatto, V. J.; Schulı, R. A.; Cleary, T. P.; Morgan, C. R.; Goli, D. M.; Rios, A. M.; Gokel, G. W. J. Am. Chent. Soc. 1985, J07, 1958-1965.

22. Tschirret-Guth, R. A.; Ortiz de Monellano, P. R. J. Org. Chem. $1998,63,9711-9715$.

23. Fifani, J.; Ramdani, A.; Tarrago, G. New J. Chem. 1977, 1, 52 l-528.

24. Ameduri, B.; Boutevin, B.; Malek, F. J. Pohm Sci.: Part A: Polym. Chem. 1994, 32, 729.740.

25. Lehn, J. M.; Sauvage, J. P. J. Am. Chen. Soc. 1975, 97, 6700-6707. 